\title{
Skopje: Rebranding the Capital City through Architecture and Monuments to Remake the Nation Brand
}

\section{Sabina Cvitković}

University of Ljubljana, Faculty of Social Sciences, Department of marketing communications, Slovenia

e-mail:sabina@cvitkovic.hr

\section{Mihael Kline}

University of Ljubljana, Faculty of Social Sciences, Department of marketing communications, Slovenia

e-mail:mihael.kline@fdv.uni-lj.si

\begin{abstract}
The paper examines the ideological underpinning and the level of persuasion and authenticity of the architectural upheaval in Skopje, accentuating the annihilation of the socialist period spent within Yugoslavia and the inclusion of a single dominant ethnicity. The paper is the first to suggest the co-branding of the city and nation brand, where attribute associations are transferred from the city brand to the nation brand and back. The paper contributes to the academic codification of the concept of rebranding.
\end{abstract}

Key words: rebranding, city, nation, co-branding, Skopje, Macedonia. 


\section{Introduction}

This paper suggests that the architectural upheaval in Skopje, the capital of the Republic of Macedonia, is the visualization of the ideology and political power that serves as the communicative and persuasive tool to rebrand the city and subsequently remake the nation brand as a direct antecedent of Alexander the Great. In addition, architecture and monuments, particularly the monument commemorating Alexander the Great, are used as the carriers of desirable meanings transferred to the city brand. The paper is the first to suggest that the city and nation brand form a permanent co-branding where the attribute associations transfer from city to nation brand and back.

Unlike the dominant voices of place and nation branding which suggest that branding is an apolitical strategy "gradually supplanting nationalism" (van Ham, 2001: 3) this paper suggests that branding strategies in a post-socialist context are predominantly political constructs aimed at the repositioning of the capital cities, the redefinition of a nation, the annihilation of socialism and the inclusion of a single dominant ethnicity. Although researchers like Ashworth and Kavaratzis (2009), Greenberg (2000), and Parkerson and Saunders (2005) have paid attention to place branding, little is known about the ideological underpinning of branding strategies in a post-socialist context, particularly in Southeastern Europe. Also, most of the studies deal with cities in the western world showing a clear bias in scholarship on city branding (Lucarelli and Berg, 2011). As a result, the literature on place branding is rich, but it does not capture the intricacies of such a specific context. In addition, the literature review reveals a lack of papers exploring the interconnectivity of city and nation brands. Also, the usage of the concept of rebranding is widespread within journalist papers which use the concept without it having been broadly codified in academic scholarship. This paper fills this void.

Previous studies on the transformation in Skopje are focused on urban planning (Mariotti and Penčić, 2015; Stefanovska and Koželj, 2012), archeology and history as a tool in national identity construction (Danforth, 1993; MacDonald, 2014), the use of constructed environments as a signifier of identity (Koziura, 2014), urban branding (Muratovski, 2013) and semiotic regimentation of public communication (Graan, 2016).

This paper is situated within the critical tradition on place and nation branding; it adopts a critical and interpretative approach and uses case study analysis to support proposed theses. The paper opens with a literature review on identification theory, culturally defined nations, strategies of place and nation branding followed by rebranding codification. The paper further reviews the main building concepts and explains the connectivity between architecture and place branding. Next, problem definition is developed, main theses are stated and the methodology is clarified. The case study analysis consists of relevant historical processes significant for Macedonian nation-building and the architectural transformations of Skopje. Then findings are merged and propositions for the bottom-up creation of the Macedonian nation brand are provided. The paper concludes with potential outcomes of the ideological underpinning of branding strategies in a post-socialist context. 


\section{Literature review}

\subsection{Identification as a cornerstone of new nation brand acceptance}

Identification is a concept borrowed from psychology and here is used to stress the importance of identification in terms of acceptance of the rebranding of the Macedonian capital and hence the remaking of the nation brand. Identification theory in psychology states that in order to achieve psychological security, every individual actively seeks identity and ways to enhance and protect this identity (Bloom, 1990). Identification stands for "a oneness with or belongingness with an entity where the individual defines him or herself in terms of the entity to which he or she is a member" (Mael and Ashforth, 1992:104). According to Hall (1996) "identification is constructed on the back of a recognition of some common origin or shared characteristics with another person or group, or with an ideal, and with the natural closure of solidarity and allegiance established on this foundation" (Hall, 1996:2).

\subsection{Culturally defined nations}

This chapter aims to underline the practice of initiators to invent the nation through the creation of culture, the construction of monuments and public spaces and establishing continuity with a suitable past, often directed toward the exclusion of "others". This paper adopts the view of culturally defined nations where scholars like Ernest Gellner, Eric J. Hobsbawm and Benedict Anderson turned toward the idea that national cultures had to be somehow created (Zubrzycki, 2010). Tradition "includes both 'traditions' actually invented, constructed and formally instituted and those [...] attempt to establish continuity with a suitable historic past" (Hobsbawm, 1983:1). Furthermore, "'tradition' is deliberately invented and constructed by a single initiator" (Hobsbawm 1983:4). As suggested by Zubrzycki (2010), invention refers to the creation of myths, symbols, traditions, national holidays, memorial days, public spaces, the construction of monuments and national symbols as vehicles of national cohesion, i.e. the creation of a national identity through a homogenous national culture and often practiced annihilation of other cultures. In addition, Anderson (2006) suggests that nation is an imagined political community and that "nationality, or [...] nation-ness, as well as nationalism, are cultural artifacts of a particular kind" (Anderson, 2006:4), whilst Gellner (1964) underlines that "nationalism [...] invents nations where they do not exist" (Gellner, 1964:169).

\subsection{The ubiquitousness of the brand concept}

This chapter aims to provide a collection of different definitions and conceptions of place and nation branding. This paper adopts the view that a brand "can be understood in terms of a set of attributes" (Park et al., 1996), a perception that lives primarily in the consumer's mind and can be defined as "an associative network, a system in which everything connects" (Franzen and Moriary, 2015:265). 


\subsubsection{Nation branding}

Research on nation branding offers different approaches and accentuates different perspectives. For example, Anholt (2007) and Szondi (2008) underline the interconnectivity of public diplomacy and nation branding; Gudjonsson (2005) emphasizes the role of government in changing a nation's image; Anholt (2003) and Graan (2016) stress the top-down control in nation branding implementation whilst scholars like Hakala and Lemmetyinen (2011) and Volcic and Andrejevic (2011) stress bottom-up co-creation. In addition, Dinnie (2008) underlines the role of culture. Writings on the role of national identity in nation brand creation are credited to scholars such as Aronczyk (2007), Jansen (2008), Kaneva (2011, 2012). According to Dinnie (2008) a nation brand is "the unique, multidimensional blend of elements that provide the nation with culturally grounded differentiation and relevance for all of its target audiences" (Dinnie, 2008:5). Jansen (2008), Volcic and Andrejevic (2011) and Kaneva (2012) argue that branding reinterprets national identity, introduces new nations and "seeks to reconstitute nationhood at levels of both ideology and praxis" (Kaneva, 2012:4). Most of the literature conceives nation branding as apolitical marketing strategy or a "post-ideological" form of reputation management for nations that targets external markets rather than an inner-orientated culturalpolitical measure that targets citizens of the national state (Kaneva, 2011; Varga, 2013). Furthermore, Aronczyk (2007) argues that nation branding is an updated form of nationalism. These claims are opposite to van Ham (2001) who suggests that branding is "gradually supplanting nationalism" (van Ham, 2001:3). Additionally, Kaneva (2011) suggests that the ability of nation branding in post-socialist contexts to pacify nationalism remains dubious. The bottom-up based concept of nation brand co-creation emphasizes the engagement and empowerment of citizens to decide what should be portrayed about their nation (Hakala and Lemmetyinen, 2011; Volcic and Andrejevic, 2011). According to Braun et al. (2013), residents can be vital participants in the place branding process. In this sense, Anholt (2007) emphasizes the importance of living the nation brand and "getting everybody in the country to speak with one voice" (Anholt, 2007:31).

\subsubsection{Place branding}

Place branding literature focuses on city branding (Ashworth and Kavaratzis, 2009; Greenberg, 2000; Parkerson and Saunders, 2005), city rebranding (Bennett and Savani, 2003; Boland, 2013), political ideology (Gertner, 2007), tourism-based destination branding (Hall, 1999; Morgan et al., 2004), region branding (Anderson, 2007), the role of culture (Philo and Kearns, 1993; Bianchini and Ghilardi, 2007; Hornskov, 2007), etc. As Hall (1999) suggests, destination branding in Central and Eastern Europe "possesses a strong ideological underpinning" (Hall, 1999:228). Urry (1995) suggests that one's sense of place is culturally constructed. However, Philo and Kearns (1993) stress that the selling of places is "a conscious and deliberate manipulation of culture" (Philo and Kearns, 1993:3-4). Whilst most of the literature examines place branding within tourism studies, little is known about how place brands contribute to the co-creation of nation brand. In addition, most of the stud- 
ies deal with cities in the western world showing a clear bias in scholarship on city branding (Lucarelli and Berg, 2011), whilst the amount of literature on rebranding remains modest.

\subsection{Rebranding cities: attributing new meanings to cities}

As suggested by Muzellec and Lambkin (2006), most of the writing on rebranding is journalistic in nature. In corporate literature, rebranding is defined as the "creation of a new name, term, symbol, design or a combination of them for an established brand with the intention of developing a differentiated (new) position in the mind of stakeholders and competitors" (Muzellec and Lambkin, 2006:805).

Here it is argued that rebranding is characterized by the attribution of new meanings to different market categories through the $3 \mathrm{R}$ prerequisites of renaming, restructuring and repositioning that results in the creation of a new image in consumers' minds. ${ }^{1}$

The brand name is an essential part of brand identity and it can affect "the favorability, strength and uniqueness of the brand associations" (Keller, 1993:9). The restructuring stands for a new model of governance directed toward increased competitiveness. Repositioning includes the change of psychological aspects of a brand and the creation and placement of a desired brand in the target customers' minds (Czinkota et al., 2001; Wong and Merrilees, 2006). Boland (2013) sees the rebranding process as significant planning projects that are physically transforming the city where old and negative images are replaced in order to create a new dynamic place identity.

Here city rebranding is defined as a politically instigated visionary project that is aimed at attributing new meanings to a city and wiping out the old and often undesired images so that the renewed brand can deliver economic prosperity, greater tourist demand, cultural attention within domestic and international customers and can serve as a vehicle to remake the nation brand.

\subsection{Celebrity endorser: carrier of desirable meanings aimed at creating the brand}

Meanings are crucial in the creation of brands and rebranding and this paper uses the concept of meaning transfer to show how citizens' encounters with architectural upheaval and monuments elicit desirable meanings that are subsequently attributed to a city brand. The meaning of a brand can stem from any perception of or experience related to the brand whilst every contact with the brand can result in forming an association with the brand in memory (Franzen and Moriarty, 2015:264). Alexander the Great here serves as the celebrity endorser where his credibility, image ability (Lynch, 1960) and symbolic properties move towards the city brand and

$\mathbf{1}$ This paper has taken and modified the $3 \mathrm{R}$ pillars from the Accenture consultancy transformation as presented in Kaikati (2003). 
back whilst the meanings associated with him become associated with the brand of Skopje in the minds of citizens. From a meaning transfer perspective McCracken (1989), suggests that the symbolic properties of the celebrity endorser reside in the celebrity and move in both directions, from celebrity to consumer good and from good to consumer. In other words, "meanings associated with the celebrity become associated with the product in the mind of the consumer" (Gwinner, 1997:147). Furthermore, each endorser is a carrier of "not a single meaning, but an interconnected set of meanings" (McCracken, 1989:313).

\subsection{The transferability of attribute associations}

This chapter accentuates the transferability of brand attributes from one brand to another. Brand associations include attributes, benefits (functional, experiential or symbolic) and overall brand attitudes (Keller, 1993). Attributes are descriptive features of a product or service which relate to what a consumer thinks the product or service is or has and can be classified into product-related attributes (a product's physical composition or a service's requirements) and non-product-related attributes (price, packaging, user imagery and usage imagery) (ibid.). Co-Branding is a derivation of the words cooperation and brand and is characterized by the transferability of brand attributes from two brands (Park et al., 1996; Baumgarth, 2003). In addition, Aaker and Keller (1990) suggest that the original brand has associations that will be potentially helpful to the extension, suggesting the transfer of desirable associations that extension is missing.

\subsection{Linking architecture and place branding}

Ideological underpinning of architecture is an important source for the debate on the impact of architecture on rebranding cities. Most studies focus on the role of architecture and monuments in nation identity construction and expression (Philo and Kearns, 1993; Verschaffel, 1999; Delanty and Jones, 2002; Jones, 2011; Light and Young, 2013), architecture as ideology and a tool for the expression of political/ authoritarian leaders (Cavalcanti, 1997; Žižek, 2009; Kaika, 2010), urban transformations in a post-socialist context (Tsenkovaand Nedović-Budić, 2006; Stanilov, 2007) and the role of architecture in city branding (Kavaratzis, 2005; Muratovski, 2012; 2013). Throughout history the city has served as the visual representation of nation, political power and ideology; the city is the point of maximum concentration for the power and culture of a community and a place where culture materializes in the built environment, parks, memorials, and marketplaces that with time become visual symbols of local identity (Mumford, 1970; Zukin, 2004). Architecture has been the universalistic expression of civilization and an important way to codify collective identities such as the nation (Delanty and Jones, 2002; Jones, 2011). Monuments as strong manifestations of architecture are voluminous, visible, lasting and tangible symbols that stand as commemorative devices, signs of power and markers of memory and history (Epps, 2001; Forest and Johnson, 2002; Smith, 2009; Verschaf- 
fel, 1999). According to Žižek (2009) "what the official ideology cannot openly talk about can be shown by the mute signs of a building".

Each leader set out to celebrate a political order by means of the construction of urban and architectural settings conceived to embody the ideology on which a new era is based and to commemorate the political achievements and purposes of his autocratic regime. The monumental urban and architectural settings were built to display political power expressing the prestige and grandeur of autocratic regimes and their leaders (Cavalcanti, 1997:81).

The power of branding cities through architecture lies in the power of creating associations with a wealth of cultural heritage attributing a symbolic value, alongside its functional value (Kavaratzis, 2005). This is done through what Lynch (1960) calls image ability, "that quality in a physical object which gives it a high probability of evoking a strong image in any given observer" (Lynch, 1960:9). However, as Riza (2015) underlines, "in most cases contemporary iconic architecture is not representing or referring to local culture and authenticity" (Riza et al., 2015:272). In cities, squares are the meeting points where representative architecture displays the city and the nation culture and history on a grand scale. City squares are the center of city events and social nodes where people can be a part of the public realm and physically become a part of the larger community (Zakariya et al., 2014).

\section{Problem definition}

The aim of this paper is to examine the ideological underpinning and the level of persuasion and authenticity of the architectural upheaval in Skopje. In addition, the paper aims to reveal how symbolic meanings that elicit edifices and monuments transfer to Skopje and subsequently to the modern-day Macedonian nation brand. Furthermore, questions are raised as to whether the rebranding of Skopje is aimed at the annihilation of the socialist period within Yugoslavia and the inclusion of only the dominant ethnicity and which are the outcomes of the top-down single minded control in implementing branding strategies.

\section{Theses}

Based on the defined problem and literature review of the described concepts this paper suggests the following three theses.

Building on the literature on the role of culture in inventing nations, architecture as the expression of political power and ideology and the role of architecture in place branding this paper suggests the following thesis:

T1: The architectural upheaval represents the visualization of ideology and a form of cultural manipulation characterized by the lack of authenticity, credibility and coherence in repositioning Skopje from a socialist city to a city having the appearance of an ancient European city and subsequently the remaking of the Macedonians as a nation belonging to Europe, having direct connections with the ancient Macedonians, antecedents of Alexander the Great. 
Building on the findings on culturally defined nations where culture is often used to annihilate others, this paper suggests the following thesis:

T2: The branding strategy is aimed at the annihilation of the Macedonian socialist period and the half-century within Yugoslavia and the inclusion of only the dominant ethnicity in branding strategies.

Based on the findings on top-down and single-minded control in nation branding implementation and bottom-up co-creation this paper suggests that:

T3: Branding strategy based on a top-down approach is causing problems with internal identification and external adaptation

\section{Methodology}

This paper employs a meaning-based approach to qualitative research. According to Orlikowski and Baroudi (1990), the aim of interpretive research is to "understand how members of a social group, through their participation in social processes, enact their particular realities and endow them with meaning" (Orlikowski and Baroudi, 1990:14). Interpretative methods start from the position that our knowledge of reality is a social construction by human actors (Walsham, 2006). The paper applies case study analysis, the preferred strategy when "how" or "why" questions are being posed and when the focus is on a contemporary phenomenon within a real-life context (Yin, 1994).

\section{Rebranding Skopje and remaking the Macedonian nation brand in perspective}

The following is a review and analysis of crucial time periods in the development of the Macedonian nation-building process from the very beginning to the present.

\subsection{The pre-historical Macedonian nation-building process until 1944}

Macedonia is a geographical region in the central part of the Balkan Peninsula and under the Macedonian king Philip II (359-336 BC), the Kingdom of Macedonia reached its maximal boundary covering what today is Aegean (Greek) Macedonia, most of Vardar Macedonia (the modern-day Republic of Macedonia) and Pirin (Bulgarian) Macedonia (Rossos, 2008). Alexander the Great (356-323 BC) was born in the ancient city of Pella, situated northwest of Greek Thessaloníki as the son of Phillip II. During his conquests Alexander founded many cities, many of which bore his name, and spread the Greek language and culture throughout his empire. According to Burger (2008) Alexander marks an important turning point in Greek history, closing the Classical period and the beginning of the Hellenistic world.

According to Gandeto (2002), ancient Macedonia was composed of many tribes where Macedonians served as a bulwark of ancient Hellenism, as they were situated 
between the Greeks to the south and the rest of the barbarians to the north, primarily protecting their own interests in the Balkans. Archaeological, linguistic, toponymic and written evidence indicate a gradual formation of the Macedonian tribes and Macedonian identity "through the intermingling, amalgamation, and assimilation of various ethnic elements" (Rossos, 2008:11). In the sixth century, Slavic tribes began to invade and settle in the area and they gradually assimilated the older inhabitants and consequently altered the ethnic structure of the Macedonian region (ibid.). The original city of Scupi was built a few kilometers northeast of modern day Skopje by the Dardans (Dardani) and further developed by their successors, the Illyrians (Iliri) (United Nations Development Program, 1970). In 695, the city was conquered by the Slavs and called Skopie, Skope, Skopija and similar (ibid.). Ancient Macedonia experienced several foreign invaders, including rule under the Byzantine and Ottoman empires (Parkas, 1997). Ottoman Turks ruled Macedonia from the fourteenth century until the Balkan Wars of 1912-1913 (Danforth, 1993) that led to Macedonia's territorial division between the kingdoms of Bulgaria, Greece and Serbia (later Yugoslavia). During the Ottoman period, Skopje was concentrated around the Bazaar, the commercial and trade center of the city (Stefanovska and Koželj, 2012). After the Balkan Wars, Greece acquired Aegean Macedonia, Serbia came into the possession of Vardar Macedonia, Bulgaria took part of Pirin Macedonia and Albania got small areas of Mala Prespa and Golo Brdo (Rossos, 2008). Since 1913, Bulgarian, Greek, and Serbian nationalists have been denying the existence of a separate Macedonian identity. The Germans recognized a separate Macedonian nation in 1944 (which had been under Bulgarian control) as part of their policy of encouraging local ethnicity (Borza, 1999).

\subsection{Skopje from 1945 to 1963}

During the mid 1940s, Vardar Macedonia as the People's Republic of Macedonia (later the Socialist Republic of Macedonia) was established as one of the six states of the new Federal Republic of Yugoslavia, with Skopje as its capital city. During this period a standard literary Macedonian language was developed and an autonomous Macedonian Orthodox Church was established (Danforth, 1993). With the help of the Federal Government, Skopje started its transformation from a backward provincial trading center into the third-largest city in Yugoslavia, the location of the university, the established Institute of Macedonian Language and Literature, the Macedonian Opera and Ballet and the State Philharmonic Orchestra (Kulic, 2009; Stefanovska and Koželj, 2012; United Nations Development Program, 1970). Lacking formally educated architects, Macedonian cities were modernized under the leadership of architects from Belgrade and Zagreb, Anton Ulrich in particular. However, the engagement of the first post-war city planning was assigned to Luděk Kubeš, a Czechoslovakian modernist architect and urban planner who further extended the city eastwards and westwards along the Vardar River whilst new neighborhoods were planned (Kulic, 2009; Mariotti and Pencic, 2015; Stefanovska and Koželj, 2012). 


\subsection{Skopje from 1964 to 1990}

The lack of local cultural representation in architecture and the anti-historical ideological underpinning evident in the rebuilding of Skopje after the 1963 earthquake was intended to unify the different constituting nations and symbolically represent the fraternity and equality of the people of Yugoslavia, opposing the stereotypical identification of socialism (Kulic, 2009). Awarded first prize, Tange's project of the new city was based on two metaphorical concepts, the City Gate and the City Wall, which became new city landmarks (Lin, 2010). The City Gate literally represented a gate into the city, characterized by the convergence of all traffic systems (ibid.). The name City Gate itself bears symbolic meanings of openness, movement, and communication. As Tange explained:

In applying the name City Gate we not only gave ourselves the hint that we should use something physically gate-like in this area, but we also planted in the mind of the people the understanding that this is the gate through which one enters the city of Skopje. (Lin, 2010:191).

The rebuilt city was dominated by the modernism-based brutalist architecture typified by geometric themes and raw concrete like the main post office building and telecommunication center designed by Janko Konstantinov (1974) (Figure 1), Saint Cyril and the Methodius University of Skopje by Marko Music (1974), the student dormitory "Goce Delčev" by Georgi Konstantinovski (1975) and others (Yomadic, 2013). The brutalist feel of Kostantinov's main post office adorned with raw concrete elicit meanings of openness, communication, accessibility, progress, vision and cohesion and cosmopolitanism. However, the cost of cosmopolitanism was the neglect of local representation, a claim in accordance with Riza et al. (2015) who suggest that architecture often does not represent local culture and authenticity. Attribute associations of post-earthquake Skopje are related to openness to the world, communications, the place "in-between", accessibility, progress, vision, cohesion, cosmopolitanism, socialism, politics, ideology and communism. These attribute associations were subsequently directed toward the remaking of an open, cohesive and cosmopolitan nation.

\subsection{Skopje from 1991 to the present}

With the dissolution of Yugoslavia in 1991, Macedonia declared independence and started using its new constitutional name, The Republic of Macedonia. The ongoing Skopje $2014^{2}$ project includes a great number of ideological edifices (Žižek, 2009) like the Museum of the Macedonian Struggle and the new Archaeological Museum of Macedonia. The architectural and other professional communities refer to the ongoing transformation as an antiquisation - the practice from the Renaissance of giving a city the appearance of ancient Rome or Athens, which could be seen in Italy

2 A video presenting the Skopje 2014 project is available at the link below: https://www.youtube.com/watch? $=$ =cAWamdmP2Sw 
and all over Europe (Koteska, 2011). In addition, many existing buildings including the Government Building, Parliament House and the central telecommunication and post office have had their facades replaced or elements have been added to blend into the architectural makeover (Graan, 2016) as presented in Figure 2. In addition, the city's renewal includes a colossal 22 meter high statue known as Warrior on a Horse. The monument represents Alexander the Great dominating Ploštad Makedonija ("Macedonia Square") as presented in Figure 3, formerly known as Ploštad Maršal Tito (Figure 4), and the Triumphal Arch Porta Makedonija ("The Gate of Macedonia") as presented in Figure 5.

Figure 1

The central post office building designed by Janko Konstantinov

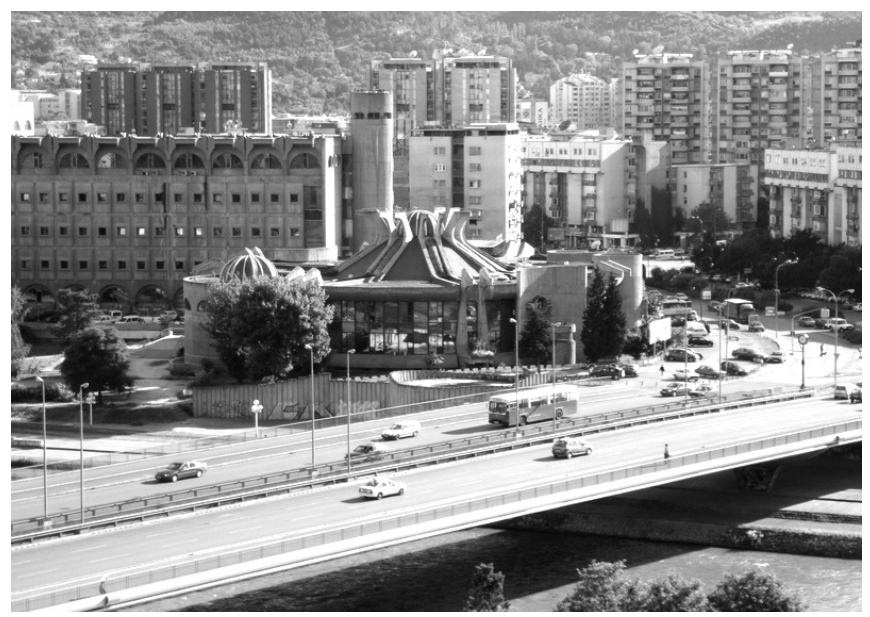

Source: Skyscapercity.com (2013)

Figure 2

The central post office building covered with gypsum to blend into the new architectural makeover of Skopje

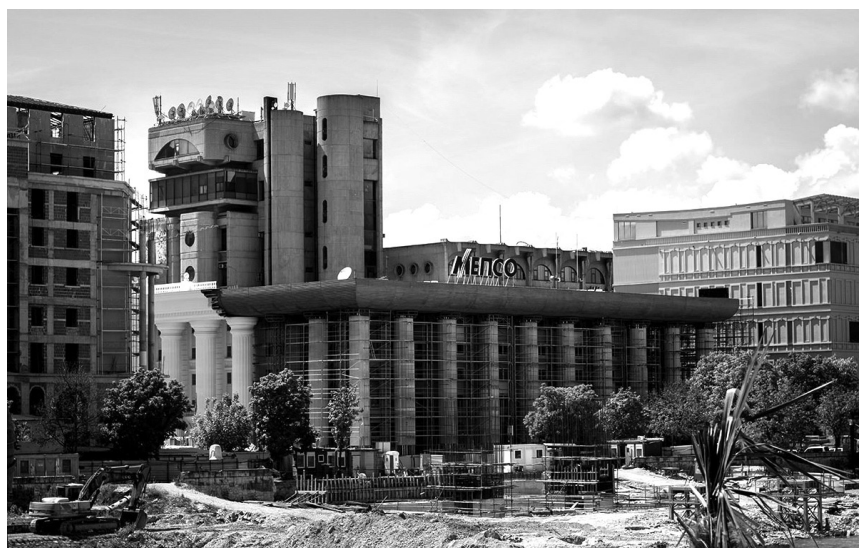


Moreover, the architectural upheaval is completely neglecting the growing Albanian minority which makes up more than thirty percent of the population; not a single monument or building has been renewed or erected to include Albanians in the changing visualization of the city.

Buildings covered with gypsum are here seen as a visualization of ideology and political power directed toward the annihilation of an almost half-century long period within Yugoslavia. Meanings attributed to Kostantinov's building today are related to antiquity, history, past. Once of raw concrete, the facade of the main post office in Skopje is today covered with gypsum and is directed toward the reimagining the city to resemble ancient Rome or Athens and awaken the attribute associations of belongingness to Europe, the cradle of civilization and democracy.

Figure 3

The staging of Alexander the Great on Ploštad Makedonija

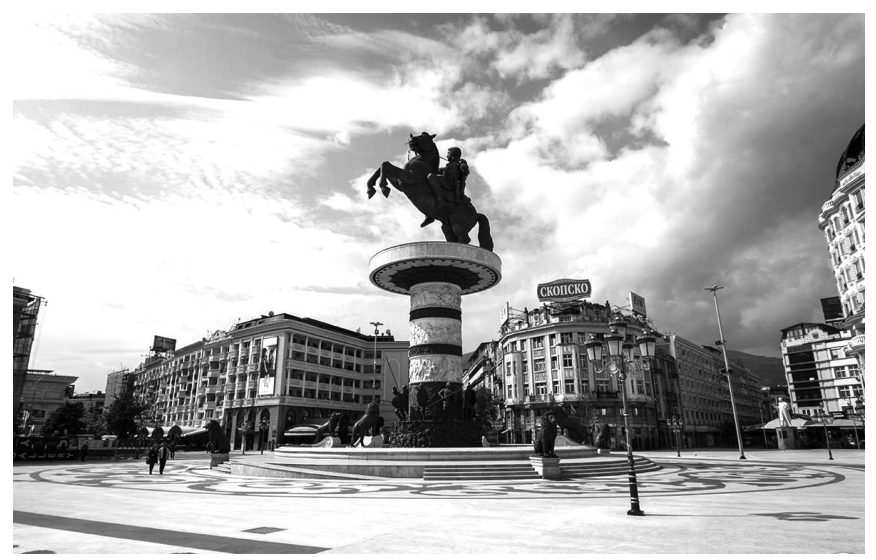

Source: Thebohemianblog.com

Figure 4

Ploštad Maršal Tito between 1980 and 1990

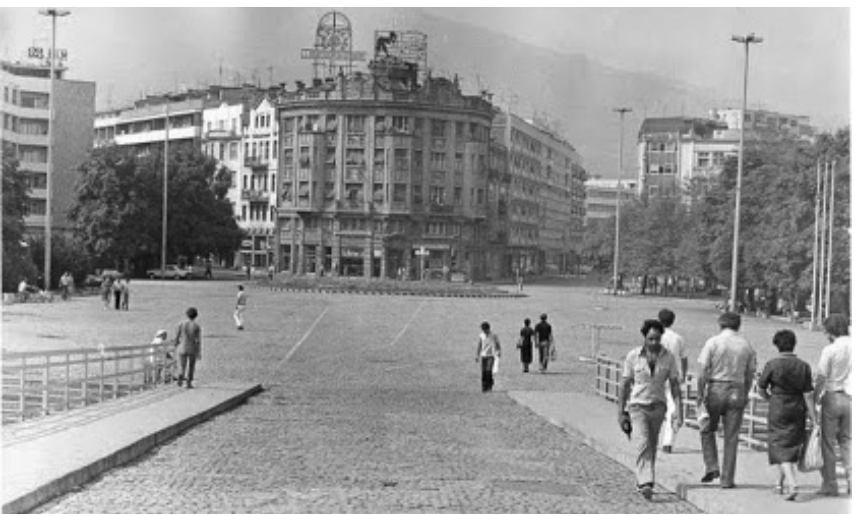

Foto: Filip Petrovski 
During the socialist period Ploštad Maršal Tito served as an urban public space where people would meet; however it was unable to accommodate many other activities besides political gatherings and concerts. The meanings that spring from the name are here related to socialism, politics, leadership, communism and ideology. The staging of the monument to Alexander the Great, the commission of a great number of monuments to historical figures like Tzar Samuel, Justinian I, Dame Gruev and Goce Delčev and the renaming of the square to Ploštad Makedonija, represents probably one of the biggest transformations of such an urban public space. The renaming and the use of the word "Makedonija" relate to statehood, nation-ness, ancient kingdom, and territory covering Greece, Bulgaria, Macedonia and Albania. The square today is a center of people's diverse activities, such as carriage rides. The 22 meter high monument to Alexander has become a new city landmark where the form and the size of the new landmark are used "to reinforce meaning" (Lynch, 1960:40). In addition the surrounding buildings covered with gypsum are used to strengthen the image ability (Lynch, 1960) of the monument. Meanings related to Alexander are victory, history, power and the territory reaching to Asia and call into question the Slavic roots of the Macedonian nation.

The Triumphal Arch, Porta Makedonija, situated on Ploštad Pela (Pella Square) between Sobranie na Republika Makedonija (The Assembly of the Republic of Macedonia) and Ploštad Makedonija as presented in Figure 5, is staged to celebrate important events in Macedonian nation-building and to commemorate historical figures evident in a number of dedicated inscriptions.

Figure 5

The Triumphal Arch Porta Makedonija destroyed by the Colorful Revolution

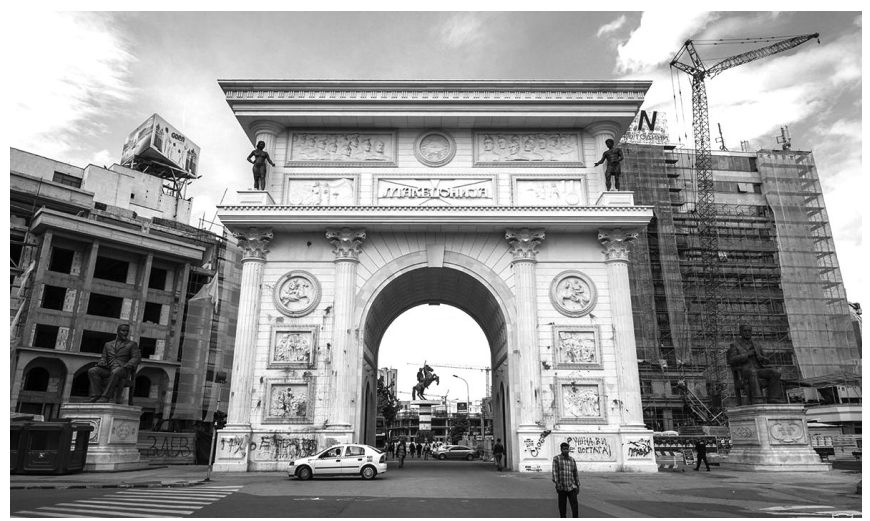

Source: Thebohemianblog.com

As suggested by Culture Minister Elizabeta Kanceska Milevska the arch "symbolizes the great victory of the Macedonian civilization of peace and its many centuries of struggle for independence" (Build.mk online, 2012). In addition, reliefs on the arch are dedicated inscriptions to the pile-dwelling settlement in the Bay of the Bones in Ohrid, Alexander the Great, King Samuel, King Marko and Karpoš, Ilinden, the exodus from Aegean Macedonia and 8 September 1991, Macedonian independence 
day (ibid.). The Triumphal Arch is here to commemorate historical figures and to accentuate the long history of the Macedonian nation. The meanings of such an edifice in the minds of citizens relate to history, antiquity, significance, struggle, revolution and independence that are subsequently transferred to the brand of the city. Also, the relation to antiquity is strengthened through the name of Pella Square where the arch is staged as it is a reference to the ancient Greek city where Alexander was born. In addition, the reshaping of the surrounding area was carried out with a new "baroque feel" facade at Pelagonija and EVN buildings surrounding the arch. This was undertaken in order to strengthen the image of the Triumphal Arch which happens "when the landmark coincides with a concentration of association" (Lynch, 1960:101). However, the authenticity of the arch is here compromised as the monument to Krste Misirkov, "an outspoken and unambiguous advocate of Macedonian linguistic and national separatism [...] who called for the recognition of Slavs in Macedonia as a separate nationality - Macedonians" (Danforth, 1995:50), staged near it is associated with Slavs and not ancient Macedonians. Such confusing meanings are also evident in Most na umetnost ("Art Bridge") where the commission of monuments to different historical figures contribute to the lack of authenticity, credibility and coherence in rebranding the Macedonian capital. In addition, the reimagining of urban public spaces is primarily attributed to the former Macedonian prime-minister Nikola Gruevski of the conservative VMRO-DPMNE, the main initiator who excluded citizens from deciding what should be portrayed about their city and nation. Street protests, such as the Prva Arhi Brigada ("The First Archi Brigade") and \#ШаренаРеволуиија ("Colorful Revolution") are a form of identity protection and the result of identification problems with the new upheaval where citizens of Skopje are unable or unwilling to recognize and accept the top-down imposed common origin related to ancient Macedonians.

\section{Findings and recommendations}

This part presents the totality of outcomes presented in the case study analysis and the recommendations for the bottom-up co-creation.

\subsection{The repositioning of Skopje and its authenticity, credibility and coherence (T1)}

The repositioning of Skopje from a socialist city famous for its modernist architecture to a city having the appearance of ancient European cities is characterized by a lack of authenticity, credibility and coherence where the initiators failed to persuade the citizens in the ancient origin of the nation. Efforts to remake the nation having direct connections with antiquity and Alexander the Great were materialized in the architecture resembling the Renaissance architecture adorning western European capitals that celebrated the style of ancient Rome and Athens. However, the staging of monuments to historical figures like Alexander the Great and Krste Misirkov, as well as many others, elicit opposing and confusing meanings that are being attributed to the city. Such attributes, when transferred to the nation brand represent the failure in the revision of the nation brand having a direct connection with ancient Macedonians, antecedents of Alexander the Great. These findings support the first thesis. 


\subsection{Annihilation of the socialist period and the inclusion of a single dominant ethnicity (T2)}

The architecture from the socialist period is either left to decay or covered with the new architectural elements aimed to increase the strength of persuasion in the ancient origin of the nation and the annihilation of the socialist period within Yugoslavia. In addition, not a single monument or building has been renewed or erected to include Albanians in the rebranding of the city. Therefore, here it is suggested that the branding strategy is characterized by the annihilation of an almost half-century long period within socialist Yugoslavia and the inclusion of only the dominant ethnicity, having been in accordance with the nationalist underpinning of nation branding in a post-socialist context. This confirms the second thesis.

\subsection{The outcomes of the top-down imposed branding strategy (T3)}

The top-down imposed branding strategy in Macedonia is resulting in many problems, primarily with respect to internal identification and cohesion problems that can potentially lead to the political disintegration of the country. Skopje's rebranding is lacking in two-way communication between the leaders and the people of Skopje who are experiencing an inability or unwillingness to identify with the ongoing renewal and are destroying the newly erected buildings and monuments. A potential solution to the problem is the bottom-up co-creation and inclusion of the Albanian minority in the process of rebranding, similar to the one in New Zealand where citizens were asked to choose the future appearance of their national flag. The paper suggests that a bottom-up branding strategy should be built on the legacy of Mother Theresa, a Catholic Albanian born in Skopje, and should accentuate such things as the cultural diversity of the country which is located on the crossroads between East and West. A culture-orientated bottom-up co-creation of nation brand would allow the constituent nations and the citizens of the Republic of Macedonia to become the creators of a future orientated nation brand. These findings are supporting the third thesis.

\section{Conclusion}

This paper has presented the ideological underpinning of the architectural upheaval in Skopje characterized by a lack of authenticity, credibility and coherence where the initiators have failed to persuade citizens in the ancient origin of the nation. The backward branding strategies in post-socialist Southeastern Europe are based on the monumentalizing of urban public spaces; the initiators of cultural rebranding exhibit strong similarities with authoritarian leaders who use architecture as a communicative and persuasive tool, the visualization of ideology and the symbol of political power, where the edifices staged during their intendance will forever serve as a reminder of underlining nationalistic discourses in post-socialist societies. Such communication results in deeper inner polarizations and external confrontations, evident in repeated riots, disputes with the neighboring states and inability to access European institutions. The paper suggests that the relation to antiquity needs to 
be more gradually implemented and communicated, taking into consideration the length of time needed for internal identification and outward acceptance.

This paper is the first to suggest that the co-branding process between city and nation brand is characterized by the transferability of attribute associations from city to nation brand and back. The paper has also contributed to the academic codification and wider understanding of the concept of rebranding. The main limitations are due to the research methodology that influenced the interpretation of the findings, a single case study analysis and the limited number of analyzed artifacts. Additional multi-case papers aimed at the wider understanding of the concept of rebranding and the usage of architecture and urban planning as the leading communication tools in branding strategies are needed.

\section{References}

1. Aaker, D. A. and Keller, K. L. (1990). Consumer Evaluations of Brand Extensions. Journal of Marketing, 54: 27-41.

2. Anderson, B. (2006). Imagined Communities: Reflections on the Origin and Spread of Nationalism. London and New York: Verso.

3. Andersson, M. (2007). Region branding: The case of the Baltic Sea region. Place Branding and Public Diplomacy, 3 (2): 120-130.

4. Anholt, S. (2003). Brand new justice: The upside of global branding. Oxford: Butterworth-Heinemann.

5. Anholt, S. (2007). Competitive Identity: The New Brand Management for Nations, Cities and Regions. New York: Palgrave MacMillan.

6. Aronczyk, M. (2007). New and improved nations: Branding national identity, in: Calhoun, C. and Sennett, R. (Eds.). Practicing culture. New York: Routledge, pp. 105-128.

7. Ashworth, G. and Kavaratzis, M. (2009). Beyond the logo: brand management for cities. The Journal of Brand Management, 16 (8): 520-31.

8. Baumgarth, C. (2003). Wirkungen des Co-Brandings - Erkenntnisse durch Mastertechnikpluralismus, Wiesbaden: Deutscher Universitäts - Verlag/GVW Fachverlage.

9. Bennett, R. and Savani, S. (2003). The rebranding of city places: an international comparative investigation. International Public Management Review, 4 (2): 7087.

10. Bianchini, F. and Ghilardi, L. (2007). Thinking culturally about place. Place Brand Public Diplomacy, 3 (4): 280-2866.

11. Bloom, W. (1990). Personal identity, national identity and international relations. Cambridge: Cambridge University Press.

12. Boland, P. (2013). Sexing up the city in the international beauty contest: the performative nature of spatial planning and the fictive spectacle of place branding. Town Planning Review, 84 (2): 251-274.

13. Borza, E. N. (1999). Macedonia Redux, in: Frances B. Titchener and Richard F. Moorton (Eds.). The Eye Expanded: Life and the Arts in Greco-Roman Antiquity. Berkeley: University of California Press, p. 249-266. 
14. Braun, E.; Kavaratzis, M. and Zenker, S. (2013). My city - my brand: the different roles of residents in place branding. Journal of Place Management and Development, 6 (1): 18-28.

15. Build.mk online (2012). “ПортаМакедонија" свеченопретставенанајавноста. Available at: http://build.mk/porta-makedonija-svecheno-pretsta/. Accessed on 11 April 2017.

16. Burger, M. (2008). The Shaping of Western Civilization: From Antiquity to the Enlightenment. New York: Broadview Press.

17. Cavalcanti, M. de B. U. (1997). Urban reconstruction and autocratic regimes: Ceausescu's Bucharest in its historic context. Planning Perspectives, 12: 71-109.

18. Czinkota, M. R.; Ilkka A. Ronkainen; Michael H. Moffett Eugene O.; Moynihan (2001). Global Business. Orlando: Harcourt.

19. Danforth, Loring M. (1993). Claims to Macedonian Identity: The Macedonian Question and the Breakup of Yugoslavia. Anthropology Today, 9 (4): 3-10.

20. Danforth, Loring M (1995). The Macedonian Conflict: Ethnic Nationalism in a Transnational World. New Jersey: Princeton University Press.

21. Delanty, G. and Jones, P. R. (2002). European Identity and Architecture. European Journal of Social Theory, 5 (4): 453-466.

22. Dinnie, K. (2008). Nation branding: concepts, issues, practice. London and New York: Routledge.

23. Epps, B. (2001). Modern spaces: building Barcelona, in: Resina, J. R. (Ed.). Iberian Cities, pp.148-194.

24. Franzen, G. and Moriarty, S. (2015). The Science and Art of Branding. New York: Routledge.

25. Forest, B. and Johnson, J. (2002). Unraveling the Threads of History: Soviet-Era Monuments and Post-Soviet National Identity in Moscow. Annals of the Association of American Geographers, 92 (3): 524-547.

26. Gandeto, J. S. (2002). Ancient Macedonians: Differences betweenthe Ancient Macedonians and the Ancient Greeks. Lincoln: iUniverse, Inc.

27. Gellner, E. (1964). Though and Change. London: Weidenfeld and Nicolson.

28. Gertner, D. (2007). Place branding: Dilemma or reconciliation between political ideology and economic pragmatism? Place Branding and Public Diplomacy, 3 (1): 3-7.

29. Graan, A. (2016). The Nation Brand Regime: Nation Branding and the Semiotic Regimentation of Public Communication in Contemporary Macedonia. Signs and Society, 4 (S1): 70-105.

30. Greenberg, M. (2000). Branding cities: a social history of the urban lifestyle magazine. Urban Affairs Review, 36 (1): 228-63.

31. Gudjonsson, H. (2005). Nation branding. Place Branding 1 (3): 283-298.

32. Gwinner, K. (1997). A model of image creation and image transfer in event sponsorship. International Marketing Review, 14 (3): 145-158.

33. Gwinner, K. P.; Brian V. Larson and Scott R. Swanson (2009). Image transfer in corporate event; Sponsorship: Assessing the Impact of Team Identification and Event-Sponsor Fit. International Journal of Management and Marketing Research, 2 (1): 1-15.

34. Hakala, U. and Lemmetyinen, A. (2011). Co-creating a nation brand "bottom up". Tourism Review, 66 (3): 14-24. 
35. Hall, S. (1996). The Question of Cultural Identity, in: Hall, S.; Held, D; Hubert, D.; Thompson, K. (Eds.). Modernity: An Introduction to Modern Societies. Massachusetts: Blackwell Publishers.

36. Hall, D. (1999). Destination branding, niche marketing and national image projection in Central and Eastern Europe. Journal of Vacation Marketing, 5 (3), 227-237.

37. Hobsbawm, E. (1983). Introduction: Inventing Traditions, in: Hobsbawm, E. and Ranger, T. (Eds.). The Invention of Tradition. New York: Cambridge University Press, pp.1-14.

38. Hornskov, S. B. (2007). On the management of authenticity: culture in the place branding of Øresund. Place Branding and Public Diplomacy, 3 (4): 317-331.

39. Jansen, S. C. (2008). Designer nations: Neo-liberal nation branding - Brand Estonia. Social Identities, 14 (1): 121-142.

40. Jones, P. (2011). The Sociology of Architecture: Constructing Identities. Liverpool: Liverpool University Press. eBook Collection (EBSCOhost). Web. 5 Oct. 2016.

41. Kaika, M. (2010). Architecture and crisis: re-inventing the icon, re-imag(in)ing London and re-branding the City. Transactions of the Institute of British Geographers, 35: 453-474.

42. Kaikati, J. G. (2003). Lessons from Accenture's 3Rs: rebranding, restructuring and repositioning. Journal of Product \& Brand Management, 12 (7): 477-490.

43. Kaneva, N. (2011). Nation Branding: Toward an Agenda for Critical Research. International Journal of Communication, 5: 117-141.

44. Kaneva, N. (2012). Nation Branding in Post-Communist Europe: Identities, Markets, and Democracy, in: Kaneva, N. (Ed.). Branding Post-Communist Nations: Marketizing National Identities in the New Europe. New York and London: Routledge, pp. 1-22.

45. Kavaratzis, M. (2005). Branding the City through Culture and Entertainment. The AESOP 2005 Conference, Vienna, 13-18 July 2005.

46. Keller, K. L. (1993). Conceptualizing, Measuring and Managing Customer-Based Brand Equity. Journal of Marketing, 57 (January): 1-22.

47. Koteska, J. (2011). Troubles with history. Available at: (http://www.artmargins.com/index.php/2-articles/655-troubles-with-history-skopje-2014\#ftn_artnotes1_3). Accessed on 6 January 2011.

48. Kulic, V. (2009). Land of the in-between: modern architecture and the state in socialist Yugoslavia, 1945-65. PhD Thesis, Austin: University of Texas.

49. Light, D. and Young, C. (2013). Urban space, political identity and the unwanted legacies of state socialism: Bucharest's problematic Centru Civic in the postsocialist era. Nationalities Papers, 41 (4) 515-535.

50. Lin, Z. (2010). Tange and the Metabolist Movement: Urban Utopias of Modern Japan. Abingdon and New York: Routledge.

51. Lucarelli, A. and Berg, P. O. (2011). City branding: a state-of-the-art review of the research domain. Journal of Place Management and Development, 4 (1): 9-27.

52. Lynch, D. (1960). The Image of the City. Cambridge and London: M.I.T. Press.

53. Mael, F. and Ashforth, B. E. 1992. Alumni and their alma mater: A partial test of the reformulated model of organizational identification. Journal of Organizational Behavior, 13: 103-123. 
54. Mariotti, J. and Pencic, D. (2015). Changing Perspectives of Urbanity during Socialism and after: the Case of Two Neighborhoods in Skopje. Studies in History E Theory of Architecture, 3: 174-182.

55. McCracken, G. (1989). Who is the Celebrity Endorser? Cultural Foundations of the Endorsement Process. Journal of Consumer Research, 16: 310-321.

56. Morgan, N.; Pritchard, A. and Pride, R. (2004). Destination branding: Creating the unique destination proposition. Boston: Elsevier.

57. Mumford, L. (1970). The Culture of the City. San Diego: A Harvest/HBJ Book.

58. Muratovski, G. (2013). Urban Branding: The Politics of Architecture. Design Principles and Practices: An International Journal - Annual Review, 6: 45-58.

59. Muzellec, L. and Lambkin, M. (2006). Corporate rebranding: destroying, transferring or creating brand equity? European Journal of Marketing, 40 (7/8): 803-824.

60. Orlikowski, W. and Baroudi, J. J. (1991). Studying information technology in organizations: Research approaches and assumptions. Information Systems Research, (2): 1-28.

61. Park, Whan C, Sung Youl Jun and Allan D. Shocker (1996). Composite Brand Alliances: An investigation of Extension and Feedback Effect. Journal of Marketing Research, 23 (November): 453-466.

62. Parkas, C. C. (1997). The United States, Greece, and the Macedonian Issue: The Tito Legacy that Haunts the Southern Balkans. World Affairs, 159 (3): 103-108.

63. Parkerson, B. and Saunders, J. (2005). City branding: can goods and services branding models be used to brand cities? Place Branding and Public Diplomacy, 1 (3): 242-64.

64. Philo, C. and Kearns, G. (1993). Culture, History, Capital: A Critical Introduction to the Selling of Places, in: Kearns, G. and Philo, C. (Eds.). Selling Places: The City as Cultural Capital, Past and Present. Oxford: Pergamon, pp. 1-31.

65. Reynolds, W. H. (1965). The role of the consumer in image building. California Management Review, 7 (3): 69-76.

66. Rossos, A. (2008). Macedonia and the Macedonians: A History. Stanford: Hoover Institution Press.

67. Stanilov, K. (2007). The Post-Socialist City, Urban Form and Space Transformations in Central and Eastern Europe after Socialism. Dordrecht: Springer.

68. Stefanovska, J. and Koželj, J. (2012). Urban planning and transitional development issues: The case of Skopje, Macedonia. Urbaniizziv, 23 (1): 91-100.

69. Stern, B.; George M. Zinkhan and Anupam Jaju (2001). Marketing images: Construct definition, measurement issues, and theory development. Marketing Theory Articles, 1 (2): 201-224.

70. Szondi, G. (2008). Public Diplomacy and Nation Branding: Conceptual Similarities and Differences. Den Haag: Netherlands Institute of International Relations 'Clingendael'.

71. Tsenkova, S. and Vedović-Budić, Z. (2006). The Urban Mosaic of Post-Socialist Europe, Space, Institutions and Policy. Heidelberg: Physica-Verlag.

72. United Nations Development Programme (1970). Skopje Resurgent: The Story of a United Nations Special Fund Town Planning Project. New York: United Nations.

73. Urry, J. (1995). Consuming Places. London: Routledge.

74. Van Ham, P. (2001). The Rise of the Brand State: The Postmodern Politics of Image and Reputation. Foreign Affairs, 8 (5): 2-6. 
75. Varga, S. (2013). The politics of Nation Branding: Collective identity and public sphere in the neoliberal state. Philosophy and Social Criticism, 39 (8): 825-845.

76. Verschaffel, B. (1999). The monumental: on the meaning of a form. The Journal of Architecture, 4: 333-336.

77. Volcic, Z. (2008). Former Yugoslavia on the World Wide Web: Commercialization and branding of nation states. International Communication Journal, Gazette, 70 (5): 395-413.

78. Volcic, Z. and Andrejevic, M. (2011). Nation Branding in the Era of Commercial Nationalism. International Journal of Communication, 5: 598-618.

79. Walsham, G. (2006). Doing interpretative research. European Journal of Information Systems, 15: 320-330.

80. Wong, H. Y. and Merrilees, B. (2006). Determinants of SME brand adaptation in global marketing. International Journal of Entrepreneurship and Small Business, 3 (3/4): 477-97.

81. Yomadic (2013). Communist architecture of Skopje, Macedonia - a brutal, modern, cosmic era. Available at: (http://yomadic.com/communist-architecture-skopje-kenzo-tange/). Accessed on 25 February 2017.

82. Zakariya, K.; Harun, N. Z. and Mansor, M. (2014). Spatial Characteristics of Urban Square and Sociability: A review of the City Square, Melbourne, Procedia - Social and Behavioral Sciences, 153: 678-688.

83. Zubrzycki, G. (2010). National Culture, National Identity, and the Culture(s) of the Nation, in: Grindstaff, L.; Hall, J. R. and Ming-cheng Lo (Eds). Sociology of Culture: A Handbook. New York: Routledge, pp. 514-529.

84. Zukin, S. (2004). Dialogue on Urban Cultures: Globalistaion and Culture in an Urbanizing World. UN-Habitat World Urban Forum, Barcelona, 13-17 September 2004.

85. Žižek, S. (2009). Architectural Parallax. Spandrels and Other Phenomena of Class Struggle. Available at (http://www.lacan.com/essays/?page_id=218). Accessed on 2 February 2017. 
Izvorni znanstveni rad

\section{Sabina Cvitković}

Sveučilište u Ljubljani, Fakultet za društvene znanosti, Odjel za tržišno komuniciranje, Slovenija e-mail:sabina@cvitkovic.hr

\section{Mihael Kline}

Sveučilište u Ljubljani, Fakultet za društvene znanosti, Odjel za tržišno komuniciranje, Slovenija e-mail: mihael.kline@fdv.uni-lj.si

\section{Skoplje - rebrendiranje glavnoga grada kroz arhitekturu i spomenike u cilju stvaranja novog brenda nacije}

\section{Sažetak}

Članak istražuje ideološku pozadinu i razinu uvjerljivosti i autentičnosti ekstremnih promjena u arhitekturi Skoplja, usmjerenih prema negiranju socijalističkog perioda provedenog u Jugoslaviji i inkorporiranju isključivo jedne dominantne etničke skupine. Ovaj je članak prvi koji sugerira kobrendiranje između brendova grada i nacije, gdje se značajke koji se povezuju s brendom grada prenose na brend nacije i obratno. Članak doprinosi akademskom kodificiranju koncepta rebrendiranja.

Ključne riječi: rebrending, grad, nacija, co-brending, Skoplje, Makedonija. 